\title{
We are what we tell: \\ An inquiry into NGOs' organizational identity and accountability
}

\begin{abstract}
Purpose - This study offers a critical inquiry into accountability vis-à-vis organizational identity formation. It investigates how accountability evolves in the transformation of an NGO operating in the field of migration management from an informal grassroots group into a fully-fledged organization.

Design/methodology/approach - The paper is the outcome of a participatory action research project on Welcome Refugees (WR), a UK based NGO. The project involved documentary analysis, focus group and semi-structured interviews, field notes, and participant observation. The analysis draws from poststructuralist theorization to explain the interplay between organizational identity and different forms of NGO accountability over time.

Findings - The study shows how different forms of accountability became salient over time and were experienced differently by organizational members thus leading to competing collective identity narratives. Organizational members felt accountable to beneficiaries in different ways and this was reflected in their identification with the organization. Some advocated a rights-based approach that partially resonated with the accountability demands of external donors, while others aimed at enacting their feelings of accountability by preserving their closeness with beneficiaries and using a need-based approach. These differences led to an identity struggle that was ultimately solved through the silencing of marginalised narratives and the adoption of an adaptive regime of accountability.

Practical implications - The findings of the case are of practical relevance to quasi-organizations that struggle to form and maintain organizational identity in their first years of operation. Their survival depends not only on their ability to accommodate and/or resist a multiplicity of accountability demands but also on their ability to develop a shared and common understanding of identity accountability.
\end{abstract}

Originality/value - The paper problematizes rather than takes for granted the process through which organizations acquire a viable identity and the role of accountability within them.

Keywords: accountability, organizational identity formation, $\mathrm{NGO}$, narrative, migration. 


\section{Introduction}

With the neoliberal restructuring of State intervention, NGOs are increasingly called upon to act on problems of public concern (Gray et al., 2006), such as immigration (McPhail et al., 2016). These organizations are said to be the best candidates for this role as their mission is to take care of the suffering of others. This social mission has for a long time made these organizations immune to public scrutiny, but recent scandals involving popular NGOs have ultimately put them in the spotlight (Agyemang et al., 2019; McDonnell and Rutherford, 2019). As a result, the last decades have witnessed a growing interest in academic debate around their accountability (Uddin and Belal, 2019; O'Dwyer and Unerman, 2008; O’Dwyer and Boomsma, 2015; O’Leary, 2017; Agyemang et al., 2019).

This emerging literature has mainly focused on NGOs' difficult endeavour of juggling different accountability demands (Uddin and Belal, 2019; O'Dwyer and Unerman, 2008; O'Dwyer and Boomsma, 2015; O’Leary, 2017; Agyemang et al., 2019). However, this literature has rarely investigated how these demands play out vis-à-vis the (trans)formation of organizational identity. With a few exceptions (Kuruppu and Lodhia, 2019; Stockenstrand, 2019), the intertwined relationship between NGOs' accountability and organizational identity has indeed been largely overlooked (Agyemang et al., 2019). Moreover, no previous accounting studies have investigated the role of accountability in the evolution of a "community of practice" (Fiol and Romanelli, 2012) within an organization. A reason for this might be that most of these studies have focused on mature organizations (Cordery et al., 2019) where identity conflicts (Chenhall et al., 2016) are already partially silenced by established hegemonic relations. An NGO's organizational identity is thus often assumed to be fixed, unproblematic, and clearly definable.

Examining the role of accountability in NGOs' organizational identity formation processes is on the contrary of primary importance as size and organizational development are key factors when it comes to understanding what "an NGO accountability might look like" (Gray et al., 2006, 321). Therefore, this study aims to explore rather than take for granted the formation of organizational identity and the role that accountability plays in it, by addressing the following research question: How is accountability implicated in organizational identity formation processes? The analysis addresses this question by exploring the evolution of a UK based NGO from an informal grassroots group to a fullyfledged organization operating in the field of migration management.

To help understand accountability vis-a-vis organizational identity formation, the study draws from previous theorizations of NGOs' accountability and poststructuralist understanding of organizational identity and identity formation processes (Brown, 2006, Whetten \& Godfrey, 1998; Sveningsson and Alvesson, 2003; Gioia et al., 2010; Glynn \& Abzug, 2002; Corley and Gioia, 2004; Humphreys and Brown, 2002). By offering a nuanced understanding of how the interplay of multiple forms of accountability evolves in identity formation processes, the study aims to contribute to critical accounting studies on NGOs' accountability (Uddin and Belal, 2019; O'Dwyer and Unerman, 2008; O’Dwyer and Boomsma, 2015; O'Leary, 2017; Agyemang et al., 2019) and extend the few management 
and accounting studies that have investigated identity conflicts in organizations (Chenhall et al., 2016; Stockenstrand, 2019; Humphreys and Brown, 2002).

The paper is structured as follows. The following two sections offer an overview of the relevant literature on NGO accountability and introduce the concept of organizational identity informing the study. The research design with details on data collection and analysis is then described, leading to case analysis, discussion, and conclusions.

\section{NGOs' accountability}

Contrary to state actors, NGOs are not elected and entrusted by the public through a process of democratic representation and need to rely on a variety of donors to sustain their activities. However, economic dependence from donors and a duty of care towards the suffering 'other' often require these organizations to discharge different, and at times competing, accountability obligations (Everett \& Friesen, 2010).

On the one hand, donors encourage a formal 'calculative accountability' (Lowe et al., 2012; Kamuf, 2007; Roberts, 1991) based on "'objective facts', hard evidence, and numbers that speak for themselves" (Baker, 2014, 2), as reflected in the wide range of (accounting) information required, for instance, in grant applications (O’Dwyer and Boomsma, 2015; Duval et al., 2015; Chenhall et al., 2010). To discharge accountability towards donors, i.e. upward accountability, NGOs are increasingly called on to satisfy performance reporting requirements and measure their social impact (O'Leary and Smith, 2020). On the other hand, this calculative accountability threatens to distort and erode NGOs' missions, ultimately undermining their legitimacy and threatening their viability (Cordery et al., 2019; Duval et al., 2015; Everett \& Friesen, 2010). Formal and calculative forms of accountability indeed presuppose a hierarchical relationship between an accountee (the principal) and an accountor (the agent) that fails to capture the multiple meanings of accountability (Roberts, 1991) characterising NGOs.

In such settings, individuals are not only "being held responsible" but are also "feeling responsible" (O'Dwyer and Boomsma, 2015, 40-41; Ebrahim, 2003). Accountability becomes "an intrinsic experience in daily organizational life" (Fry, 1995, 181; Roberts, 1991; McKernan, 2012), a profound sense of moral obligation (Shearer, 2002; Dixon et al., 2006; O'Dwyer and Unerman, 2008) that often finds expression in informal and alternative accounts (Cordery et al., 2019). NGOs' accountability indeed goes well beyond formal and economic accountability (Cordery et al., 2019; Costa and Andreaus, 2020). There is a moral expectation, testified by the level of media scrutiny to which they are subjected (Gray et al., 2006), that these organizations will enact a social mission. Thus, "managers (or activists) running [these] organisations take responsibility for shaping their organisational mission and values, for whether (and, if so, how) to open themselves to public or external scrutiny, and for assessing their performance in relation to their goals" (Unerman and O'Dwyer, 2006, p. 356), developing what Unerman and O'Dwyer (2006) have termed 'identity accountability'. 
Furthermore, this same moral expectation also drives the work of organizational members, especially volunteers, who build a complex and not merely economic relationship with the organization to which they belong (Chenhall et al., 2017). NGOs' organizational members are not merely driven by the economic motif but by the purpose of the organization, a purpose that they try to align with their 'felt responsibility' (Agyemang et al., 2017; O'Dwyer and Boosma, 2015; Dewi et al., 2019). "It is this purpose, as expressed in these entities' missions and values, that plays an important role in organisational performance" (Cordery et al., 2019, p. 6). The identification of the organizational members with organizational identity is therefore a key characteristic of NGOs ' accountability insofar as individuals join these organizations precisely to enact those values and beliefs that they share with the organization (Chenhall et al., 2017).

These values and beliefs are in turn enacted in the relationship that organizational members build with a variety of stakeholders, especially beneficiaries, towards whom they feel a "genuine sense of responsibility" (Yang and Northcott, 2018; Agyemang et al., 2019, 4). It is indeed in their encounter with the suffering 'other' that organizational members express NGOs' missions (O'Leary, 2017) while simultaneously developing "a shared vision within the organization" (Agyemang et al, 2017). This is particularly the case for grassroots NGOs whose "very essence is one of complex, close interaction" with beneficiaries (Gray et al, 2006, p. 336). This close interaction typically does not require formal accountability systems in place and facilitates other forms of accountability characterized by empathy, i.e. a deep understanding of foreign experiences (Costa et al., 2018; Gray et al, 2006). Yet, organizational actors may variously experience and enact their felt accountability towards beneficiaries by either simply fulfilling beneficiaries' needs or rather embracing a rights-based approach that sees them "working alongside rights holders rather than working on behalf of beneficiaries" (O'Leary, 2017, p. 23).

Since closeness and informality have been identified as key elements of NGOs' identity and accountability (Gray et al, 2006), there is a common finding in the accounting literature that the virtuous cycle that links organizational members' felt accountability with the discharging of downward and upward accountability through identification (see Fig. 1) is routinely threatened by the increasing need for NGOs to secure economic capital and discharge formal and calculative forms of accountability. In other words, while securing economic capital, NGOs may struggle to preserve their identity and cultural capital (Chenhall et al., 2010, p. 746). Whereas this is a shared conclusion, no previous accounting studies have actually investigated the interplay between accountability and organizational identity as an NGO evolves from an informal grassroots group into a fully-fledged organization (Agyemang et al., 2019). To investigate and explain how different forms of accountability are implicated in the formation of organizational identity, this study draws from a poststructuralist understanding of organizational identity discussed in the following section. 


\section{Organizational identity: a narrative approach}

Identity is one of the most intriguing puzzles in our lives. Unsurprisingly, this concept has gained the attention of scholars across a wide range of disciplines, from psychology to business research (Giddens, 1991; Whetten \& Godfrey, 1998; Sveningsson and Alvesson, 2003; Gioia et al., 2010). Despite people perceiving identity as profoundly personal, organizations are also said to have an identity, and organizational identity has become a primary focus of investigation in management literature (Alvesson, 2010). Yet, the concept of 'collective identity' remains highly problematic (Gioia et al, 2000; Brown, 2006). Personal identity and organizational identity are indeed ontologically different phenomena (Gioia et al, 2000). The conceptualization of organizations as if they are superpersons fails into the traps of reification and anthropomorphism (Brown, 2006). Compared to personal identity whose stability is partially genetically mediated, organizational identity appears more fluid, complex and variegated (Gioia et al., 2010). Personal identity is surely far from monolithic and it can be said that "a parliament of selves exists in each person" (Sveningsson and Alvesson, 2003, 1165). Nevertheless, the metaphorical reduction of organizational identity to personal identity risks overemphasis on continuity, distinctiveness, and homogeneity, where multiple social processes of negotiation, resistance, and contestation are at play (Brown, 2006).

Following Brown (2006), this study argues that a narrative perspective offers interpretive lenses which solve the limitations of a monolithic approach to organizational identity, thus also providing insightful analytical lenses for this case analysis. A narrative perspective conceives the identities of organizations as being constituted by "the totality of collective identity-relevant narratives authored by participants" (Brown, 2006, p.735). Identity-relevant narratives that members author to make sense of organizational identity are constitutive of both collective identity and identification processes (Brown, 2006; Humphreys and Brown, 2002). Organizational members indeed author different stories about what is enduring and distinctive about their organizations and, in doing so, they simultaneously construct their own identities (Humphreys and Brown, 2002; Fiol and Romanelli, 2012). Personal identity and organizational identity, whilst distinctive, are therefore inextricably intertwined. Disidentification and identification dilemmas can arise whenever individual self-narratives are disconnected from the dominant identity narrative of the organization. On the contrary, people identify with the organization to which they belong when authoring consistent self-and-collective narratives, thus positively and actively connecting with the organization (Elsbach, 1999). Organizational members' identification with organizational identity shapes the collective identity narratives that they develop in an effort to make sense of their organizational experience.

These identity narratives are not elaborated in a vacuum but are "intensely governed" (Humphreys and Brown, 2002, p. 423) as they are told "from a particular point of view, for a particular audience, and are thus imbued with motive" (Brown, 2006, p. 738). In particular, the organizational members' capacity to authorize and elaborate identity narratives is always constrained by stakeholders who are actively involved in the construction of collective identity (Brown, 2006; Humphreys and Brown, 
2002). Not only do stakeholders define the conditions of identity intelligibility and recognition so that identity claims always occur within predefined 'regimes of truth' (Butler, 2005), they also author identity narratives that are constitutive of organizational identity. Organizational identity is indeed constructed not only internally but also through external interaction (Gioia et al, 2000, p. 146). Stakeholders' identity narratives can thus threaten internally authored organizational identity and members' identification processes (Stockenstrand, 2019).

For instance, in her study of two chamber orchestras, Stockenstrand (2019) has shown how external demands of financial accountability led to a struggle between musicians' and orchestra's managers as the latter endorsed identity claims that resonated with donors but not with the musicians' professional values. The latter were key elements of organizational members' identification with the organization. Similarly, Chenhall et al (2016) have explained how financial performance requirements by powerful stakeholders can feel in conflict with an organizational identity hinged upon values of social justice, thus leading to internal identity conflicts.

These previous studies thus testify that, although competing identity claims can at times co-exist unproblematically through the deployment of a variety of identity management strategies (Chenhall et al, 2016), there are instances where some identity claims become hegemonic and other are silenced in a struggle between organizational actors equipped with different (definitional) power (Sveningsson and Alvesson, 2003). Humphreys and Brown (2002), for instance, have analysed how senior managers in a top institution tried to control identity formation by imposing their collective identity narrative and reducing identity plurality. Organizational identity is thus ultimately a "locale for competing hegemonic claims" (Brown, 2006, p. 731).

In this study, I further argue that identity struggles become particularly problematic when organizations are still in their infancy and hence more exposed to 'authoritative' narratives elaborated by external stakeholders (O'Leary and Smith, 2020), as compared to fully-fledged organizations with formal organizational structures. In this initial process of identity formation, organizational members constantly engage in forming, negotiating, sharing and contesting identity claims (Clegg et al, 2007; Corley and Gioia; 2004; Fiol and Romanelli, 2012; Gioia et al., 2013; Czarniawska and Wolff, 1998). They experience 'identity ambiguity' (Corley and Gioia, 2004) and a 'meanings void' (Gioia et al., 2010) that prompts them to engage in experiential contrasts with other organizations to achieve an "optimal distinctiveness" (Gioia et al., 2010).

In co-constructing organizational identity, organizational members also "take responsibility for shaping their organisational mission and values, for whether (and, if so, how) to open themselves to public or external scrutiny, and for assessing their performance in relation to their goals" (Unerman and O'Dwyer, 2006, 356). The development of identity accountability thus becomes a constitutive element of the dynamics of resistance, control, and hegemony that gradually come to define organizational identity. Yet, this specific interrelationship between identity accountability and organizational identity 
(formation) and how this, in turn, influences members' identification and the discharging of other forms of accountability, has remained largely overlooked.

To help explore this issue in the light of the theorization of organizational identity developed above, and of previously discussed notions of NGOs' accountability, the above research question, i.e. How is accountability implicated in organizational identity formation processes? can be further detailed as follows: How does accountability shape the identity-relevant narratives authored by organizational members? How does it influence hegemonic discursive struggles concerning organizational identity? These questions will be addressed in the case analysis, following the explanation of the research method and context in the next section.

\section{Research Method and Context}

This study is the result of participatory action research conducted by the author from January, 2019 to October, 2020. The project involved a UK based organization, Welcome Refugees (WR) ${ }^{1}$, operating in the field of migration management.

\subsection{Organizational overview and context}

Welcome Refugees (WR) is a Community Interest Company founded in 2017 and evolved from a voluntary group that assisted immigrants in the wake of the major European refugee crisis since September 2015. WR's aim is "to help refugees and asylum seekers to integrate into and become part of their new community" (WR's website) through the provision of a variety of services, including advocacy and guidance in the development of professional skills and education.

At the time of this research, the organization consisted of a team of approximately 20 unpaid volunteers variously involved in carrying out the organizational activities. Among the volunteers, the organization counted on a chair, 4 directors - 2 of which served as full-time committed caseworkers an administrative officer, and around 14 occasional volunteers. Since its foundation, the organization had been working on 79 cases, which can be detailed as 127 adults and 98 children, making a total of 225 beneficiaries. However, the organization witnessed a significant $65 \%$ increase in the number of cases in 2019 as compared to the previous year. This increasing demand resulted in mounting pressure on the two caseworkers and persuaded the organization to apply for a small development grant with the National Lottery to cover their salary. This subsequently awarded grant required the organization to engage in and account for a 'development process' attesting the maturing of WR into a formal organization from the grassroots network model which had been the basis of its success. Moreover, the grant could cover these expenses only for the time of the development phase, following which WR

\footnotetext{
${ }^{1}$ Fictitious names are being used to maintain the anonymity of the participants.
} 
needed to find other sources of funding to ensure the survival and sustainability of the organization in the years to come.

It is in this context that the WR's chair and directors contacted the author to receive support. The objective of the participatory action research was to explore how the individual members of the group were experiencing the new phase marked by the creation of the Community Interest Company and the beginning of the development phase funded by the National Lottery. The aim of this exploration was in turn to enhance reflexivity and to enable and guide the complete transformation of the group into a company with a mission, clear structure, and defined responsibilities, and able to sustain its operations in the long term. The study then followed the traditional stages of participatory action research (Kelly, 2005; Cameron and Gibson, 2005; Costa and Andreaus, 2020), which generally consist of three main cycles: the planning cycle, the acting cycle, and the review cycle.

\subsection{The planning cycle}

Having identified the community partner and formalized the objective of the project, the planning cycle involved documenting the current situation through the collection of relevant secondary and primary documents (Cameron and Gibson, 2005).

The analysis could rely on a variety of sources. The documents analysed included meeting notes provided by the chair of the organization, company newsletters, publicly available material such as data available on the company's website, financial documents such as the balance sheets and budgetary plans, and funding applications and reports. These documents provided an overview of the practices and policies developed in the organization since its foundation and precious insights into the discussions that were taking place at the time of the research intervention.

This documentary analysis was conducted in tandem with 13 semi-structured interviews of, on average, 1 hour's duration, a focus group with 10 beneficiaries, and the active participation in several formal and informal meetings and events, including a community evening with beneficiaries and organizational members. The collection of the in-depth interviews started in February 2019 and involved a total of 13 interviewees, i.e. the chair, the 4 directors, and 8 volunteers (see Table 1). Considering the small size of the organization, the interviews collected with all the important organizational actors and the focus group with a diversified group of beneficiaries created for the author a sense of data saturation in relation to the objective of this first stage.

The interview guide revolved around organizational identity vis-a-vis the two broad dimensions of identity accountability theorized in the literature, i.e. accountability as 'being held accountable' and 'feeling accountable' (O'Dwyer and Boomsma, 2015). The interview indeed aimed on the one hand at understanding how organizational members conceived the identity of the organization in relation to the accountability demands of donors, partners, and beneficiaries, and, on the other hand, focused on the organizational members' experience of identification with the organization, and on their 'felt accountability' towards the organizational mission, values, and stakeholders. Overall, the interview 
wanted to offer an opportunity for reflection on the past, present, and future of organizational identity vis-à-vis the expectations of a variety of stakeholders, especially beneficiaries and donors.

In order to gain an understanding of the role played by beneficiaries' accountability demands in shaping the identity formation of WR, a focus group with 10 beneficiaries was also undertaken (see Table 1). The focus group aimed at assessing their knowledge about the organization, understanding their current experience, accountability demands, and gathering their suggestions and comments as to how the organization had been developing and should develop in the future. To ensure the representativeness of the findings, the beneficiaries were selected based on the following criteria: gender, typology (with and without recourse to public funding), and years of experience with WR (established and new clients). Furthermore, since most of the beneficiaries did not speak English, a mediator offered her support with translation. None of the existing volunteers and directors of WR was involved in the focus group to ensure that the beneficiaries could open up and freely express their opinions.

Both interviews and the focus group were then audio-recorded, transcribed, and analysed. The analysis aimed at identifying significant patterns of convergence and divergence in relation to organizational identity and accountability over time and across interviewees. Following a consolidated method of data analysis in identity studies (Carollo and Guerci, 2018; Harding 2008; Harding et al. 2014; Clegg et al, 2007), the data analysis focused on the participants' use of personal pronouns to isolate those instances where the interviewees were referring to organizational identity and their identification with it (by using the pronoun 'we', or 'they' in the case of beneficiaries) (Clegg et al, 2007).

Once isolated and highlighted, these collective identity narratives used by organizational members were also coded in relation to emerging constructs of accountability. For instance, organizational members who emphasised the informal character of the organization were simultaneously relating this characteristic to a need-based approach towards beneficiaries' accountability. The identification of the different forms of accountability was a two-stage process where first-order codes were grouped into more theoretical "researcher-induced second-order themes" (Gioia et al, 2010, 12; Kroezen and Heugens, 2012). For instance, first-order such as 'being close to beneficiaries', 'being responsive to beneficiaries' needs' were grouped under the code 'need-based accountability' (O'Leary, 2017), whereas the codes 'beneficiaries' empowerment' and 'enhancing beneficiaries' independency' were coded under 'right-based accountability'(O’Leary, 2017).

In the final step, the analysis consisted of a comparison of identity-accountability narratives across interviewees and over time by focusing on the examination of past, present, and future tenses. This analysis ultimately unveiled the different and at times conflicting ways in which organizational members and beneficiaries were constructing organizational identity over time and how they related accountability to this construction. 


\subsection{The acting cycle}

This first planning cycle was then followed by the acting cycle. The latter aimed at creating "consciousness and social change by working together with the target community to address an agreedupon goal" (Kelly, 2005, 70). In this stage, the project opened a process of reflexive critique in which participants could share their views about the interpretation developed by the researcher, reflect on the research findings and provide alternative interpretations (Gillis \& Jackson, 2002). During this stage, the author prepared a report which summarized the main findings from the analysis undertaken during the planning cycle. In particular, the analysis identified four main critical areas that required further collective reflection among organizational members: communication with volunteers and beneficiaries, organizational structure, (financial) accountability, and sustainability.

The report was presented to the organizational members and widely discussed during several meetings. The discussions revolved around the multiplicity of discourses and identity claims raised by the organizational members around the past, present and future of the organization and whether and how to crystalize these discourses into a temporary, yet shared, answer to the question "who we are as an organization?'. Accountability challenges related to the construction of organizational identity and ways to address them were also discussed during the meetings. For instance, the discussions revolved around which donors and beneficiaries to target in the future.

Following these meetings, some new practices were introduced such as training days for volunteers, attended by the author, where new members were offered an overview of the organization and existing members had the chance to comment on their experiences with beneficiaries. New internal policy documents such as the code of conduct for volunteers and the safeguarding and safety policy were also introduced along with ongoing documentation of existing practices and processes (e.g. the collection of information about the beneficiaries and the activities carried out). To increase beneficiaries' accountability, there was also a discussion around the opportunity to have new directors closer to the refugee experience either because they had themselves been refugees or had a close relationship with them.

\subsection{The review cycle}

These reflections and changes led to the third stage of the project, the review cycle, during which the author and the participants engaged in conversations aiming at assessing the process of development and the changes undertaken during the previous months of development with a view to the "desired future image" (Corley and Gioia, 2004, 176). This process started with the preparation of a business plan by the author in collaboration with organizational members. The business plan had two main objectives: first, to help the organization to account for the funding received by the National Lottery for the development stage and, second, to offer a rough narrative around the purpose, structure, and objective of the organization, including the changes that the organization undertook during the development stage and those that it planned to undertake in the three years following the project. The 
business plan was then discussed among the chair and the directors during several meetings. However, the finalisation of the business plan soon became a turning point as the directors could not agree on a final version. As a result, the chair and one of the caseworkers (Caseworker A) decided to resign. Moreover, whilst the business plan was submitted for the funding received by the National Lottery, it was never implemented.

The results of this period of reflection and development of a shared organizational identity narrative were then discussed by the author during informal conversations and in the context of four follow-up interviews carried out approximately one year after the beginning of the research project (see Table 1). The interviews involved the chair and the caseworker, who decided to resign following the completion of the development project, and two directors (the new chair and Caseworker B) who are still working in the organization. The interviews were recorded and analysed following the same method adopted in the planning cycle. At this stage, theoretical saturation was thus achieved through deeper rather than wider interviewing (Dai et al., 2019). Both these interviews and the informal conversations indeed afforded an opportunity for in-depth analysis. They allowed the author to gain an appreciation not only of the most recent developments in the process of organizational identity formation but also of the impact of the action research project. The latter was crucial in enhancing organizational reflexivity, helping the organizational members to crystallize their different collective identity narratives and work out a solution to their identity conflict, in this case by bringing about a radical change (i.e. a leadership change). This process and the findings from the previous two stages of the action research are discussed in the following sections.

\section{Case analysis}

\subsection{The context of identity formation}

In 2015, unprecedented inflows of irregular immigrants along the coasts of southern Europe raised international attention. The media denounced "Europe's migrant crisis" (Kingsley, 2015) and the European Commission published the first "European Agenda on Migration" in the recorded history of the Union (European Commission, 2015), inviting member states to take responsibility and allow a fair distribution of incoming migrants among the European states. The UK was considered one of the desirable destinations for irregular immigrants leaving their countries in search of a better life. However, as is often the case in human history, national states protect their boundaries depriving individuals of basic human rights: the right to move and the right to stay. The UK was not an exception to the rule. The French port of Calais soon became an encampment for irregular immigrants hoping to enter the UK, and in what was called the 'Calais Jungle', thousands of immigrants gathered in the hope of crossing the sea and finally reaching the UK.

In this context, the inaction of the British government provoked the mobilization of civil society. In reaction to the media, informal groups of citizens felt a responsibility towards the incoming migrants 
and a duty to help. The city of 'Calwer' in the UK was one of these sites where organizations of volunteers, single individuals, and local authorities began to mobilize. Among these, a local politician and educator, moved by a desire to do something to change the situation in Calais, called a meeting on Facebook saying we're thinking of working with refugees, perhaps other people who are working with refugees in Calwer would like to meet. Let's all go to the coffee bar (Chair). Forty different organisations or individuals turned up at that meeting and, soon afterwards, a smaller group of people gathered regularly with the idea of devising solutions to the refugee crisis. The group, chaired by this charismatic educator, would then become the centre of a new organization under the name Welcome Refugees (WR).

While Calais was the starting point, soon it became clear that it was not the only site where a humanitarian response was needed. The massive mobilization of civil society groups persuaded the British government to accept a quota of refugees and asylum seekers. The Prime Minister at the time, David Cameron, agreed to welcome up to 22,000 refugees from Syria by 2020, a scheme to be financed mainly by the international aid budget. Local municipalities became the main actors for the distribution and allocation of incoming migrants. Calwer City Council decided to welcome 10 Syrian families, meeting the request of the community and local organizations to welcome incoming asylum seekers. The council entrusted the management of this reception to a local charity backed up by the Church, Together for Refugees (TFR). However, the latter soon failed to provide adequate support to the needy immigrants reaching the city, who hence resorted to WR in search of help. Thus, Calais and Calwer became the two main sites where WR started to operate and grow. The following sections describe the three stages of WR's identity formation process with a view to the role played by accountability to beneficiaries and donors within.

\subsection{Stage I: (Dis-)identification and need-based accountability}

Welcome Refugees (WR) started as a group of people willing to meet the material and spiritual needs of immigrants in Calais and to help the incoming Syrian families to find their place in the local community of Calwer city. However, initially, the group had not meant to become an organization, as explained by its chair:

We resisted the organisation but we did create a small group who met on my land, in order to have a bank account and just be organised enough to be able to help other people to spontaneously do what they wanted to do [...] That's how Welcome Refugees (WR) was born. Because that tiny little group of people with a bank account and a chair and a secretary became the centre of WR (Chair).

This narrative describes the origins of WR's identity in terms of a socio-material assemblage: $a$ group of people with a bank account and a chair and a secretary (Chair). However, as time passed, more immigrants in addition to the Syrian families started to contact the group asking for help, and two 
caseworkers previously working for Together for Refugees (TFR), the NGO entrusted by the local council, joined the group. The group organized several events to facilitate the integration of the resettled Syrian families and newcomers within the local community. One of these initiatives was the so-called 'Syrian pop-up café' where refugees and asylum seekers served Syrian food to the local community, with the collaboration of the group and of a local gallery that offered the venue for the events. These events became a turning point in the formation of organizational identity. Calwer's community and the Syrian families started to identify the group as an organization facilitating the reception of asylum seekers and refugees in competition with Together for Refugees (TFR). WR's organizational identity was brought into existence through this interpellation (Butler, 1990; Althusser, 1971). By hailing 'they are a new organization', external audiences positioned the group as such (Fiol and Romanelli, 2012). A volunteer explained this process in the following terms:

The pop-up café...I mean, that was just a huge event! And so many more people than knew about us. I mean, we were on social media. [...] And then I suppose it kind of just grew from the events that we put on. That people knew about the group, people were coming in who were asylum seekers or refugees that had come on their own. And they'd found out that there's this group of people that might be able to help, and it's kind of just grown from there. (Volunteer)

It was by becoming "a community of practice" (Fiol and Romanelli, 2012), collectively engaging in some activities, that the group started to discursively articulate its identity as an organization. Within this process, WR's members engaged in a relation of difference by dis-identifying with TFR. WR's organizational identity came into being through a negative definition of identity (Clegg et al., 2007; Fiol and Romanelli, 2012; Gioia et al., 2010). In the 'story world' (Fiol and Romanelli, 2012) of WR's volunteers, WR's identity emerged as informal and independent in contrast to TFR that had a formalised structure and was dependent on big donors such as the Council and the Church. The activities of WR were indeed mainly funded by multiple small donors, "individuals touched by stories" (Chair), who did not seek to impose their agenda on WR.

In the volunteers' view, this independence from bigger funders allowed the organization to be driven by the needs of people, regardless of the institutional labels given to them. Indeed, although the organization had formally defined specific 'categories' of people that it wished to help, namely "refugees, asylum seekers and people who have no recourse to public funding" (WR website), these lines were blurred as the volunteers ultimately felt accountable to whoever knocked at the organization's door:

And then we have people who don't really fit any of those categories. So, we've had clients who are not refugees, who do have immigration problems but they... one of them had no recourse 
to public funding, the other one had been a teacher her whole life, but we took them on because we happened to have the knowledge locally. (Caseworker B)

The process of dis-identification with TFR simultaneously established a relation of sameness and belonging whereby WR's members also began to connect their self-narratives with the collective narrative that they were shaping. For instance, one of the caseworkers could relate her personal inclination and desire to take care of others with WR's distinctive characteristic of having a holistic approach to beneficiaries' needs:

I've always wanted to be the caseworker, it's what I enjoy, it's what I'm good at. The case work absolutely nurtures me, feeds me, I love doing it. I find it really fulfilling because you see somebody through from the beginning to the end of a problem. I often talk to social workers [...] and they never stay in touch with a client until the end or until the completion of a particular issue. And I get the pleasure of doing that. (Caseworker B)

Furthermore, all our participants explained that at the origin of the group there was a 'felt responsibility' (Agyemang et al., 2017; O'Dwyer and Boosma, 2015) to provide beneficiaries with a 'sense of belonging': "the value is belonging, what we do is enable people to belong here where they found themselves. So, we're offering sanctuary and belonging" (Chair). They often articulate their perceived accountability towards the marginalized as empathy, i.e. an awareness of the experience of the suffering other (Costa et al., 2018). Some volunteers could perceive the beneficiaries' experience through the (social) media broadcasting of the refugee crisis or the touching speeches of the other members of the group, while others developed a more profound awareness through self-identification: For me, it's my journey here, I'm half Argentinian, half Hungarian, I remember the moment we arrived in the UK, I remember my dad being terrified, I remember him being searched. We all have some access to an understanding on a deeper level (Caseworker B). Along the same lines, another volunteer explained: I'm originally from India. I was a political exile. I know what it's like to come and start again. Absolutely. And I just felt I wanted to do something meaningful in life (Volunteer).

Importantly, this empathy shaped the accountability mechanisms adopted by WR in this first stage of the identity formation process. The organizational members indeed thought that formal accountability was not required; informality and a need-based approach (O'Leary, 2017) were key in building a 'close relationship' with beneficiaries (Gray et al, 2006). This emerged clearly in the provision of what the organization called 'emergency help' counting as $11 \%$ of the total expenses in the year 2017-2018 (WR website). Since the beginning, this emergency help had characterised how WR had been supporting and helping the beneficiaries. An example of this emergency help was described in the following terms: 
We have about $£ 4,000$ in our account. Yesterday I bought two $£ 70$ tickets for... Well, we bought two $£ 70$ bus passes for a month for a family. The wife is pregnant and she's bleeding, so she has to go to the hospital every other day for a test. And at the moment that's costing them on the bus around $£ 5$ a day and they don't have £5 a day, they're asylum seekers. So, we bought them a monthly bus pass. (Volunteer)

This 'emergency help' was given to meet the specific needs of individuals in a given moment, but no formal criteria had been established to define which beneficiaries were entitled to receive the money. Similarly, there was not a formal system to evaluate how the donations received were being spent and whether the services offered were effective in reaching desired outcomes. Furthermore, the willingness of organizational members to be responsive to all beneficiaries' needs resulted in the development of a variety of services such as education, employment, advocacy, mental health, welfare and emergency support, immigration help, outreach, and fundraising. In the words of a volunteer: I think some of the challenges are the breadth of issues that people come to us with. Sometimes it's housing, sometimes it's mental health requirements, sometimes it's just they have no money (Volunteer). However, there were no clearly defined roles and responsibilities and the provision of these services lay in the personal commitment of unpaid volunteers.

The storytelling constituting the organizational identity formation process had thus initially become centred around the ideals of informality, independence, and need-based accountability that often characterise the identity of small grass-roots NGOs (O'Leary, 2017; Gray et al, 2006). These ideals, emerging as elements of "optimal distinctiveness" (Gioia et al., 2010, p. 1; Clegg et al., 2007), were both the result of a process of dis-identification with TFR and of volunteers' identification with the organization due to the enactment of these ideals. Volunteers indeed identified with the organization precisely because they felt that they were collectively enacting these personal values and in so doing shaping organizational identity (Chenhall et al., 2017). However, some of the volunteers soon started to produce alternative collective identity narratives which challenged precisely these ideals that had been the basis of WR's success until that point. This second stage in the identity formation process is described in the following section.

\subsection{Stage II: Competing collective identity narratives following new accountability demands}

The practices and characteristics that allowed WR to formulate a shared collective identity narrative soon appeared unsustainable to some volunteers. The reasons were mainly twofold. Firstly, the organization witnessed an increasing demand for support from beneficiaries. 52 new cases were opened during the year 2018-2019, registering a $65 \%$ increase compared to the previous year. This increasing demand resulted in mounting pressure on the two caseworkers who were devoting their full time to the organization but who, as with the other volunteers, were not being paid. Second, the beneficiaries begin to author new narratives of WR's identity and raise new accountability demands. 
In the eyes of beneficiaries, WR and TFR indeed appeared as competitors equipped with similar financial and human resources and equally accountable to them and the general public. Some beneficiaries were seeing WR as a formal and structured organization paid by the government to provide them with the necessary support rather than seeing it as a group of volunteers. For example, some beneficiaries did not believe that WR's organizational actors were volunteers but rather paid workers, as explained by this volunteer: "They don't believe it. Some of them do, of course, believe it, especially people who have worked closely with me, but quite a number of them don't believe it, and then they spread a lot of rumours" (Volunteer). Another volunteer similarly said: "Sometimes you suspect that this person feels that I am paid for this job, but I don't care if he misunderstands".

Not only were the expectations that the beneficiaries had towards TFR projected on to WR but also, whenever TFR failed in fulfilling its responsibilities, WR was called up to act and solve the problem. One of the main problems was that the beneficiaries often did not trust organizations that were supposed to help them. Whilst NGOs are typically formed to take care of vulnerable people, the type of beneficiaries that WR wished to help were vulnerable in some key respects. Many of them had survived long journeys, escaping wars, and were victims of abuse. Unsurprisingly, distrust and scepticism characterised their relationship with WR and other organizations operating in the migration management field.

This climate had the effect of spreading rumours and suspicion among the beneficiaries about the behaviour of WR's volunteers and their financial choices, such as the use of emergency help. A beneficiary for instance argued that: "Sometimes we volunteer in activities that are done by this organization, but the organization gets money, but we don't get anything” (Beneficiary). Another suspicion was that money that 'should' be spent on Syrian refugees was illegitimately used for other 'types' of refugees. Financial accountability thus became of primary importance in the eyes of the beneficiaries. Moreover, accountability collapsed into a request for full transparency (Roberts, 2009), as it emerges in the following quote:

We would like to have more details on events. For example, WR should tell us clearly that they gave 1,000 pounds for this event and they bought this and this and still we have this, so that we know what the balance is, what do they have in value... (Beneficiary)

WR responded to these accountability demands by showing that a financial accountability system was in place and accounting data were indeed shared during the annual general meetings with donors and the broader community. A volunteer, for instance, explained:

Our accounts are audited and checked so we must have proof of receipts and where we spent everything. So, in that way we're accountable technically on that way [...] So, say for instance the people I bought the bus passes for yesterday have sent me today pictures of the receipts and 
the tickets that they bought and those will go into our account system so that we have proof of where that money has gone. (Volunteer)

However, the beneficiaries were arguing that the criteria according to which things are being given should be clearer (Beneficiary) and called for a formal accountability system clarifying who was entitled to receive the money and for which purpose. The fact that WR's initiatives were mainly driven by the specific needs emerging daily had thus become problematic in the eyes of these beneficiaries who started labelling this approach as favouritism and raised allegations of lack of transparency against the volunteers. On the contrary, other beneficiaries turned the informality and ambiguity of the system to their advantage by asking WR for every sort of economic support they needed. For instance, a beneficiary asked the organization to help him pay the council tax, in spite of him having the financial capability to pay it. In the words of a participant: WR would be like their bank (Volunteer).

Moreover, not all beneficiaries were appreciating the holistic approach of WR. For those asylum seekers, to finally get the status of refugee enabling them to find employment was a primary need. Hence, they expected the organization to be more supportive and more professional, as it emerges in the words of one of the beneficiaries: They [WR] need to be more specialised, more organised - for example, I want to open my business and I need more direct help on how I can do it rather than be sent [by WR] to someone that is not trustworthy (Beneficiary). Similarly, another beneficiary argued that as an organization they should find job opportunities for us rather than leaving us with the job centres (Beneficiary).

The emergence of these accountability demands coupled with a "collective sense of overload" (Corley and Gioia, 2004, 205) opened up a debate around the sustainability of the organization, the need to optimize the use of resources and the opportunity to start paying the two caseworkers, as emerged in the words of the chair: How can we pay for their [caseworkers'] time and the central costs such as rent and thus maintain the company? If we cannot do this, we face closing WR (Chair's Report to Directors' Meeting, 26 June 2019).

These considerations had already motivated a first step in the formalization of organization identity and, in 2017, WR officially became a community interest company (CIC). The chair explained this transition as motivated by a need to better organize the resources available and attract new ones:

Whilst we are a network of 80 or 90 willing organisations or human beings, we have not got the capacity at the moment to use the help. And thus the big challenge is to create the capacity to use our help network. So, for me, WR is the network of volunteers and helpers. And so we're not getting the flow in and out of it. And so we need to formalize. We worked out that if we became a community interest company (CIC), it would allow us to remain slightly informal. But we could centralise our resources. And we also realised in making that formality, that it was time to tackle the fact that we are almost entirely held up by two people. (Chair) 
For the same reasons, WR attempted and succeeded in getting a development grant with the National Lottery Community Fund to cover some expenses, such as 6 months' office rent, equipment and furniture, the salary of an administrative officer, and the "development time" of two volunteers ( 2 days salary per week). The total budget for the 'development phase' was approx. $£ 30,000$ and was specifically designed to help WR to develop its systems and processes to attract funding that will make our work sustainable for the next few years (WR Grant Application). This is when the action research project started with the aim of documenting and facilitating this transition.

To win the grant and subsequently account for the money received, the five directors needed to formulate a new identity narrative using terms and categories centred around business concepts such as 'business plan', 'clear and measurable outcomes', 'strategic development plan', 'project delivery grant' etc. The National Lottery defined the terms within which the organizational identity of the group could become intelligible and legitimate in the transformation from an informal grassroots group to a structured company (Chair's Report to Directors' Meeting, 26 June 2019). This emerges clearly in the application submitted for the grant:

This phase will enable the WR team to review our work including goals and activities, organisational structure, systems and processes and volunteer skills. Our aim is to put in place a coherent learning and development plan for each client which results in clear and measurable outcomes. We also aim to develop robust documentation processes of our work using written, visual and audio media.

However, the National Lottery's 'authoritative discourse of accountability' (O'Leary and Smith, 2020) triggered 'identity ambiguity' (Corley and Gioia, 2004) and a 'meanings void' (Gioia et al., 2010) as, in developing "goals and activities, organisational structure, systems and processes and volunteer skills... [and] clear and measurable outcomes" (WR's funding application), the organization was called upon to reflect on those ideals of informality, independency, and need-based accountability that had constituted their shared organizational narrative. This triggered a reflection around what our purpose is, understanding what our processes are, and understanding what the underlying instincts are, that have created this way of working and what we do (Chair). This quote unveils the cognitive and pragmatic dimensions of this stage, characterized by the emergence of 'identity accountability' (O’Leary, 2017). This stage consisted of producing new meanings and understanding the processes of shaping and being shaped by the practices and narratives of the organization vis-à-vis the accountability narratives authored by the National Lottery and the beneficiaries.

In this stage, new and competing narratives of collective identity were authored by organizational members. The interviews collected in the planning cycle indeed revealed that, while serving practical purposes, the formalization of WR into a community interest company and the reception of the 
development funding was greeted with mixed feelings by the organizational actors. Different and at times conflicting narratives emerged about the identity of the organization in terms of the beneficiaries 'to target', the services to be offered and to what extent the organization should be 'managed as a company'. The co-existence of these competing narratives was depicted in the report that opened up the acting cycle of the research project centred around enhancing the reflectivity of organizational members.

The report primarily identified two main collective identity narratives emerging in the interviews. On the one hand, some volunteers begin to dis-identify with those ideals of informality and need-based accountability that had been central to organizational identity until that moment. These volunteers, especially the chair and one of the two caseworkers (Caseworker A) who were committing most of their work to 'the development project', were advocating the idea of 'formalis[ing] all processes and systems' and 'defin[ing] an organizational structure' (Development Grant Application). For them, the Development Grant could be a real opportunity for growth, internal dialogue, and for actively imagining and co-authoring alternative collective identity narratives. Despite partially experiencing the articulating and writing of their stories to appeal to the funders as a form of alienation and mis/recognition, they also believed that adopting that business language was "a means to an end" (Caseworker A) and that "it does have merits" in making the organization more professional, transparent and accountable. The caseworker, for instance, explained: "I would like there to be a clear management group with defined roles" (Caseworker A). Similarly, whilst driven by the willingness to remain faithful to the original aspiration of the organization to offer immediate help to everyone, they felt that defining clearer criteria of (financial) accountability - as a 'formal organization' would do was beneficial and necessary: It's just moving the thinking from our team from 'let me do this out of my kindness', to 'let us try and frame this in terms of what WR can do in a sustainable way' (Caseworker A). In their view, beneficiary accountability meant handing the organization over to the beneficiaries, to really work with them by, for instance, having trustees or directors who reflect the beneficiaries (Chair). Similarly, it appeared important for them to define specific work streams and target specific 'types' of beneficiaries. In other words, in their view, it was necessary to have formal accountability mechanisms in place that could address the shortcomings of the need-based approach adopted by WR.

On the other hand, the second caseworker (Caseworker B) and other volunteers were authoring another identity narrative. They felt that they could keep identifying with the organization to the extent that those ideals of informality, independence, and need-based accountability were being preserved. In their narratives, being structured and formalised had a negative connotation associated with one-off transactions typical of the "service user" vs. "service provider" relationship:

There isn't this kind of boundary [in our organization], these professional boundaries that have to be there between a provider and a user. I think also we as a team don't quite believe in those. We are not checklist employees. (Volunteer) 
This second group of organizational members saw the initiative of the development grant as a threat to the organizational identity. They were particularly concerned that the 'business-like approach' advocated in the Development Grant Application would crowd out the empathic accountability that had driven the group since its foundation. Furthermore, they wanted the organization to resist any sort of 'categorization' of beneficiaries and expand rather than restrict the base of individuals being helped. They were afraid of defining, and by defining, ending up denying support to individuals that needed it, thus failing in discharging accountability. In their view, not giving an account would also be interpreted by these beneficiaries as being an account, a refusal to provide the much-needed help (Messner, 2009). Accordingly, they perceived the emergency help as the most tangible way in which the organization discharged accountability to the suffering other, a sign of that need-based accountability that drove the organization to be responsive to the material needs of beneficiaries. Finally, they perceived that the new focus on discharging accountability to funding bodies such as the National Lottery could have come at the cost of disidentification of some volunteers with the organization, as explained here:

One of the risks, I think, might be losing people because a lot of the volunteers like the fact that [WE] is a small organisation. I'm trying to make the set up more professional by doing the forms and having systems in place so that things run, but you can become too professional. I don't think that's a good thing. (Volunteer)

Each volunteer had indeed a personal understanding of the role that they played in the organization and wanted to enact this role in a way that could satisfy their "genuine sense of responsibility and accountability to beneficiaries" (Agyemang et al., 2019). Some volunteers enjoyed the fluidity and flexibility of their involvement which ultimately differentiated their support from the work of an employee: I very much like not having a defined role. [...] That's what's so different about working in a job. You have a very defined role (Volunteer). Some of the volunteers could devote only limited time to the organization and liked to be involved in different types of activities and not to have to take the responsibility of a predefined role (Volunteer). Finally, for some organizational members, being a volunteer rather than a paid worker was not a by-product but was rather constitutive of self-identity and organizational identity. For instance, the second caseworker explained: Even if we get to the point where we have funding for wages, I would do one day a week volunteering, because I feel that you lose something when you get paid for a job. (Caseworker B).

\subsection{Stage III: Identity struggle and adaptive accountability}

The report developed and discussed during the acting cycle became the starting point of the review cycle that saw the preparation of the business plan to be submitted shortly to the National Lottery to account for the development grant. In line with the National Lottery's narrative of accountability, the 
business plan should include an organizational chart with clear roles and responsibilities, the definition of workstreams, a list of prospective beneficiaries, and a request for a budget to cover expenses in the following three years.

Whilst structured within the criteria of identity intelligibility defined by the donor, the business plan aimed to create a basis of dialogue among organizational members whereby the latter could imagine and co-author a new collective identity narrative (O'Leary and Smith, 2020). On the contrary, the business plan became the site of identity struggle between the competing identity narratives described in the previous section. The challenge of building this dialogue was described by caseworker A as follows:

We asked for meetings with them [other WR's members] to share the work with the business plan and it was a struggle to get together or to find the time ... we wanted their input and we started to do this thing about the roles and the responsibilities to do all that work and we wanted to get their feedback in order to finish up that bit about the different strands of work that it is going to be there and there was no willingness really (Caseworker A).

On the one hand, the chair and caseworker A, who had been more directly involved in devising ideas for the transformation of WR into a fully-fledged organization, were very much interested in the contents of the business plan. They wished to reappropriate the National Lottery's business-like narrative of accountability to bring positive changes in the organization. In particular, in their view, formal accountability mechanisms devised in the business plan could have helped the development of a rights-based approach (O'Leary, 2017) whereby clear criteria concerning financial accountability would have allowed the organization to reach more beneficiaries and become as inclusive as possible:

There was a big push to always be able to help people because they turned up and the other side of that, the terrible side of it is, that anybody who did not turn up got nothing. So that way of things was supposedly the most open ended way but it was excluding the vast majority of people. What happens to those that do not turn up at the door? (Chair)

A rights-based approach could also empower beneficiaries as, according to them, WR's need-based approach was infantilizing the beneficiaries all the time. The chair argued: They [the beneficiaries] came and then they would have been given help and more help but they were never empowered to walk away by the sort of help that they were given" (Chair). In the long term, the objective would paradoxically be "putting the organization out of business" (O'Leary and Smith, 2020). When asked how she would like to see the organization in 10 years' time, the chair answered: [in 10 years' time] I would like there to be no need for it. That would mean an end to the refugee situation. In her view, by 
making beneficiaries dependent on the organization, the existing practices were securing a base of beneficiaries but were unwittingly failing WR's mission.

On the other hand, other WR members had a different approach to the business plan. Its preparation was not perceived by these members as an opportunity to become co-authors of a new narrative. In their eyes, the business plan did not appear open ended and dialogic, rather they felt that it was being used by the chair and caseworker A to make their collective identity narrative hegemonic in the organization. In their view, "the business plan was being imposed" on them and their voices and perspectives were remaining unheard in the process. Caseworker B, for instance, complained with the chair and caseworker A: You never discuss this with us, you never talked to us about any of this" (Caseworker B). The way in which the business plan was reappropriating the National Lottery's business-like narrative of accountability was especially problematic for these members: "We did have a lot of discussions about it but there was something in the core of it, about us being a business and having wages like this and projecting us forward in a way that did not resonate with the rest of us" (Caseworker B).

Moreover, the business plan and related development process was seen as a distraction from the "most valuable" mission of the organization, which for them consisted of meeting beneficiaries' needs. According to these members, both the chair and caseworker A had been devoting all their time to activities other than the casework, distancing themselves from the beneficiaries: She has never been in to see a day of work, how could she know what we do?... and the other stopped doing casework some time ago" (Caseworker B). Commenting on their commitment to these activities in the previous months, another director explained:

The other two were very much losing sight of the individual client ...the focus was on non-core stuff...organizational, fundraising...that are still important but it was just not getting that key element which is 'why are we here?' We are here to work with our clients (Director).

For the majority of WR's members, the business plan was not much relevant for its contents or in virtue of its ability to crystalize/redefine the organizational identity. For them, the business plan should have rather served the purpose of conveying an image of the organization, such as 'being more professional', which would have enabled them to secure funding and then focus on the 'real work'. This approach emerged in how, for instance, caseworker B and other WR members referred to the business plan as an unimportant matter to be quickly resolved:

They were constantly pointing the finger - 'have you done it? have you submitted it?' - actually truly refusing to put in what they needed to put in for it to be finished. (Caseworker A) 
Due to these different attitudes towards the business plan, the discussions around it taking place during the management meetings became "very heated discussions" (Caseworker A). Caseworker B confided to me: "Our regular management meetings became something that we learned to dread". Such difficulties in engaging in a dialogic reflective process and agreeing on a shared collective identity narrative to crystalize in the final version of the business plan persuaded the chair to adopt a different strategy of identity management. To account for the money received from the Lottery Grant, the business plan document finalised by the chair and caseworker A was indeed submitted together with a film telling the story of WR and describing the transition experienced in the past months thanks to the funding received. In the chair's view, the film would preserve the internally driven identity claims authored by organizational members while the authoritative narrative of accountability authored by the donors and reflected in the business plan would have served other organizational purposes. However, whereas this attempt "to retain all identities while forging links between them" (Chenhall et al., 2016, 5) was perceived as unproblematic by her, it was not the same for others:

I was able to separate that in my head, ok we captured our values in the film, we captured our processes in the business plan [...] and I did not feel that they would interfere with each other, but it felt to me as if many of the directors panicked and felt that neither of those things fitted their bill anymore. (Chair)

Reflecting back on these discussions, the chair explained that the majority of the directors "panicked", "were so threatened" and that ultimately, they "staged a kind of rebellion" that led to a "coup" which ended with them requesting her to leave the organization. The chair and caseworker A indeed both resigned a few months after the completion of the development phase and a new chair, previously serving as director, was appointed. The chair who resigned felt that she had been unable to internally persuade other WR members to become co-authors of her collective identity narrative:

My passionate desire did not fit with the organization, I literally resigned this chair because they won't choose to do most of what I thought we had set out to do...they would say that their passionate desire I guess was client-facing casework, so they wanted to face the clients and felt that everything we were doing was creating a barrier between us and them. (Previous chair)

In the months following the resignation of the chair and caseworker A, WR's organizational efforts have been aimed at fostering an "adaptive accountability regime" (O'Dwyer and Boomsma, 2015, 42) whereby the preservation of the 'passionate desire' for need-based accountability is being combined with an "instrumental focus of imposed accountability" (Ibidem). The new chair explained how he and the remaining WR members have been trying to bring again to the fore the focus on casework and beneficiaries' needs: We now feel in a much more client-focused and delivery focused way, there is 
nobody who is not pretty much involved with clients, very close to clients among volunteers and paid staff so we have very much changed that focus... it is very much about whatever the client needs, we will get it. Rather than targeting specific beneficiaries, they remained open to the demands of an everchanging and broader base of beneficiaries. For instance, they were currently assisting Europeans, something that they could not anticipate before (New chair).

Furthermore, the new chair explained that whereas organizational and fundraising issues had become particularly central under the agenda of the previous chair, currently each management meeting starts with a discussion of the most important beneficiaries' cases so that all the organizational members, even the fundraising team, can be aware and be reminded of what is the core of WR's work and keep a 'close relationship' with beneficiaries: We talked about why we are paying a lot of cash out in destitution payments and they [the fundraising team] know, they can be in the office when somebody comes in for a while and can relate that individual to where so much money is going, though they don't meet many clients, they see and hear about many cases (New chair). Consequently, the organization is "now very much focused on costs associated with supporting our clients, so it is caseworkers" (New chair). Furthermore, to preserve this collective identity narrative centred around beneficiaries' needs, the directors have been particularly concerned with hiring new directors that share the "same view" and are "on the same page" (Chenhall et al., 2016) and support discussing potential concerns of volunteers on a regular basis.

This renewed focus on need-based accountability has been combined with a strategic and instrumental approach to external demands of accountability, which earned WR two successful grant applications covering the expenses of three offices and the salaries of five staff workers. As explained previously, for these WR members, accountability documents such as the business plan were not very important by virtue of their contents, but for their ability to tell a story of organizational success to external stakeholders (O’Leary and Smith, 2020; O'Dwyer and Boomsma, 2015). In line with this approach, WR's funding applications were then strategically prepared with the help of external advisers to meet donors' expectations more than serving as part of a broader internal discussion on organizational identity. For instance, a new application for a three-year National Lottery grant was prepared afresh with a view to conveying the message of 'being a sustainable organization':

The Lottery Grant application which we're in the middle of doing, which was another three years funding, is a completely fresh application and we had to do our own new approach and prove that we had funding from other sources, to show that, should they not be able to fund us in the future, we will still have a core of activities that we would maintain because that is what they need to see $[. .$.$] they want to see how you become sustainable. (Caseworker B)$

This strategic approach is reflected in a missing direct link between funding and beneficiaries' needs whereby the main objective is to "prepare more for a general cause" so that the funding can then 
be used to address the ever-changing needs of beneficiaries using a logic similar to the one underpinning the 'emergency help' described in the previous section. The new chair explained:

Although we are client-led...there is no link between that and the funding. There is not 'oh you got more people from that category, here there is some funding to deal with that'. There isn't that kind of arrangement. The funding does not follow our clients' needs. (New chair)

WR's members are thus preserving their felt accountability while gradually adhering to donors' accountability demands, although in a flexible and fluid manner. For instance, the definition of organizational roles and responsibilities was not part of the co-authoring of a collective identity narrative but rather a by-product of increasing organizational complexity and financial availability, as explained by caseworker B:

Because we could pay people, we had to formalise these roles. Because they are getting paid to do a specific job, they have a job description, and it is about evolving rather than saying "this is what we need." (Caseworker B)

This combination of formal and informal accountability measures is thus only partially the result of internal reflexivity and dialogue. WR's adaptive approach to external accountability could have indeed encouraged more reflexivity in the form of the authoring of new collective identity narratives. However, this was not the case, partially because of mutating external circumstances. The COVID-19 outbreak has indeed shifted donors' focus towards the emergency and short-term objectives. Accordingly, the three year National Lottery grant which WR's directors were targeting was also revised under COVID provision. The National Lottery only granted short term funding (6 months) focusing on the response to the emergency. The donor's short-term focus on fulfilling the immediate needs of beneficiaries resonated well with WR's felt accountability, hence WR could secure the grant. This success however also had the effect of postponing further opportunities to transform account-giving into a site of reflections around the question "who are we as an organization?", as clearly emerged in the following comment:

They wanted only 2 pages for the COVID application [...] they are interested in the emergency not in long term sustainability [...] at the moment it is very short term, we don't really care if we have got a business plan, we just care about how we deliver to people in need at the moment. (New chair) 


\section{Discussion and Conclusion}

Whilst NGOs' accountability has been much debated in the accounting literature (Chenhall et al., 2010; O'Dwyer and Boomsma, 2015; O’Leary, 2017; Agyemang et al., 2019; Everett \& Friesen, 2010; O'Leary, 2017; Roberts, 1991), no previous studies have analysed how accountability is implicated in organizational identity formation processes (Agyemang et al., 2019). This investigation is of primary importance since NGOs' accountability is deeply rooted in the enactment of a social mission shared by organizational members who identify with the organization to which they belong (Chenhall et al., 2017). Processes of identification and organizational identity formation are especially important for grass-roots organizations in their development to become fully-fledged organizations. It is indeed in these processes that organizational members develop identity accountability by "tak[ing] responsibility for shaping their organisational mission and values, for whether (and, if so, how) to open themselves to public or external scrutiny, and for assessing their performance in relation to their goals" (Unerman and O'Dwyer, 2006, $356)$.

This study suggested that the definition of this 'identity accountability' (Unerman and O'Dwyer, 2006) is never disjointed from dynamics of hegemonic (discursive) struggle wherein at times conflicting collective identity narratives compete to build a dominant organizational identity. These collective identity narratives in turn reflect organizational members' different attitudes towards upward and downward accountability and are therefore key in shaping how NGOs discharge accountability towards a variety of stakeholders (see Fig. 1). The analysis developed in the previous sections aimed at explaining the interplay of different forms of accountability in the formation of WR's organizational identity (see Fig. 2). In this respect, WR's identity formation process consisted of three main stages (see Fig. 2).

The first stage saw the transition of WR from a group of volunteers to a well-recognized organization. The analysis has shown how WR came into existence through a negative process of disidentifying with another organization, i.e. TFR (Clegg et al., 2007; Fiol and Romanelli, 2012; Gioia et al., 2010) and a complementary process of volunteers' identification with the organization due to the enactment of a set of ideals (Chenhall et al., 2017; Stockenstrand, 2019), such as informality, independence, and need-based accountability. The 'relation of difference' (Clegg et al., 2007) with TFR was indeed mediated by how organizational actors and beneficiaries understood and started to construct WR's identity. This mediated encounter with TFR and external audiences became key for the organization in the development of a first shared temporary answer to the question "who are we as an organization?". This first shared narrative revolved around ideals of informality, independence, and need-based accountability. The closeness to beneficiaries and the felt responsibility of organizational members to address beneficiaries' needs made formal accountability systems unnecessary at this stage (Costa et al, 2018; Gray et al, 2006).

However, this first stage in the formation of organizational identity was a precarious one insofar as distinctiveness and continuity started to be jeopardised by the authoring of competing collective identity 
narratives. The emergence of these narratives was partially triggered by new accountability demands of external stakeholders, i.e. beneficiaries and the National Lottery, and partially by internally driven changes in the way in which some volunteers were (dis)identifying with the organization. The 'authoritative narrative of accountability' (O'Leary and Smith, 2020) of the Lottery around transforming WR into a more 'business-like' organization indeed resonated with the felt accountability of some volunteers, especially the chair and one of the caseworkers, who saw the transition of WR toward more formalised systems of accountability as beneficial for both the organization and the beneficiaries. In particular, the transition from a need-based approach towards rights-based accountability (O'Leary, 2017) appeared to them as a new and better way to enact their felt accountability. On the contrary, other organizational members resisted this change in an attempt to preserve the need-based accountability that they saw as constitutive not only of the organizational identity but also of their identifying with the organization. The emergence of these conflicting narratives and related understanding of accountability thus came to dominate this second stage of identity formation and was effectively depicted in the context of the acting cycle.

The third stage of the identity formation process observed during the review phase of the project was in turn characterized by a struggle between the above competing collective identity narratives. The analysis reveals how an accountability document such as the business plan became the pivotal site of this identity struggle as it required WR members to co-author a consensual collective identity narrative. In mature organizations, the moulding of organizational identity generally lies in the hands of senior managers that are formally equipped with more (definitional) powers (Stockenstrand, 2019; Chenhall et al, 2016). Identity accountability is among their prerogatives and other organizational members have usually a limited voice in this process. In the case of WR, given the age of the organization, the authoring of a dominant narrative in official documents became itself controversial and subject to negotiation between organizational members with similar definitional powers.

In this process, the majority of WR's members viewed the business plan document as hegemonic rather than dialogic (O'Leary and Smith, 2020), hence they resisted its narrative and ultimately forced their authors to resign. From their position, the chair and caseworker A became gradually aware of their dis-identification with the organization and also of their inability to make their identity narratives internally persuasive. Following the silencing of their collective identity, WR witnessed a shift towards an adaptive regime of accountability (O'Dwyer and Boomsma, 2015) aimed at combining members' felt accountability towards beneficiaries with a strategic and instrumental appropriation of donors' authoritative discourse of accountability. The analysis ultimately suggests that, whilst effective for securing the much-needed resources, this approach was not as effective in fostering further critical reflection around the question "who are we as an organization?".

The findings of this study extend previous critical accounting studies on NGOs' accountability (Uddin and Belal, 2019; O’Dwyer and Unerman, 2008; O'Dwyer and Boomsma, 2015; O'Leary, 2017; Agyemang et al., 2019) in several ways. To begin with, the analysis problematizes the dichotomy drawn 
in previous studies between an 'externally imposed accountability' calling for formal accountability mechanisms, and an 'internally generated accountability' based on informal and value-based accounts (O’Dwyer and Boomsma, 2015; Ebrahim, 2003; Roberts, 1991; Chenhall et al., 2016, 2010). The above analysis indeed shows that the call for formal accountability was only partially triggered by the demands of external stakeholders and would be poorly understood in opposition to felt accountability. Some organizational members indeed believed that a formalization of accountability would have better served the beneficiaries and their felt accountability actually resonated with the external request of funding bodies (Agyemang et al., 2017). Formal accountability as opposed to informal accountability can thus allow organizational members to discharge downward accountability in a way that is consistent with their values and beliefs. Similarly, 'business-like' narratives authored by donors are not necessarily experienced in opposition to internally driven identification of organizational members with the organization. On the contrary, donors' authoritative discourse of accountability can be re-appropriated by organizational members and received in an internally persuasive mode (O'Leary and Smith, 2020).

Second, the study shows how different forms of accountability became more salient in different stages of the identity formation process (see Fig. 2). Informal accountability was relatively unproblematic in the first stage of the process but became more controversial when the organization started to expand and deal with an increasing number of demands from beneficiaries and donors. Similarly, identity accountability became particularly salient in these first years of operation when organizational mission and values were yet to be clarified, as were internal roles and responsibilities of organizational members. In this respect, the study offers an empirical answer to "an interesting unanswered question" (Gray et al., 2006, 335) as to the role of factors such as size and growth in defining the accountability of NGOs. In this respect, it should be noted that, despite the internal resistance to a business-like narrative, once the organization started to grow, a certain degree of formalization became ultimately essential to keep the operations of the organization ongoing. This transition to a more adaptive regime of accountability occurred without sacrificing the role of felt accountability in driving the development of the organization.

Third, the analysis offers a more nuanced understanding of identity accountability (O'Dwyer and Boomsma, 2015; Ebrahim, 2003; Unerman and O'Dwyer, 2006; Yang and Northcott, 2018), a concept that has been introduced in the accounting literature but hardly problematized vis-a-vis organizational identity and other forms of accountability. Previous studies have correctly argued that "it is the organization and its managers who decide the scope of their own accountability" (Taylor et al., 2014, p. 637; O'Dwyer and Unerman, 2008), as part of shaping their 'identity accountability' (O'Dwyer and Unerman, 2008). This process, I argue, is characterized by dynamics of (narrative) resistance, hegemony, and identity struggle partially driven by the different ways in which organizational actors wish to enact their felt responsibility and conceive downward accountability. Whereas closeness and empathy (Gray et al., 2006; Costa et al., 2018) were perceived by some organizational members as key in discharging downward accountability, others experienced their felt accountability (Agyemang et al., 
2019; O'Leary 2017) in terms of a responsibility towards an 'abstract other', hampered rather than enabled by closeness.

Finally, the study also adds to the small number of management and accounting studies that have investigated identity conflicts in organizations (Chenhall et al., 2016; Stockenstrand, 2019; Kuruppu and Lodhia, 2019; Humphreys and Brown, 2002). These studies have unveiled the importance of effectively integrating or at least aggregating "social mission and economic rationales" (Chenhall et al., 2016), "inward accountability" and "managerial logic" (Stockenstrand, 2019), in order to solve conflicts over organizational identity. This study shows that factors such as discursive leadership and the age of the organization also become relevant when devising managerial solutions to identity conflicts. The implementation of management identity strategies is indeed particularly challenging in organizations like WR wherein internal hierarchical accountability is yet to be formed and organizational members are endowed with similar (definitional) power.

Another factor of complexity that emerged in the study was indeed the nature of employment, i.e. whether the organization had a paid or volunteer workforce. In this respect, this study differs from many previous studies on NGOs' accountability (O'Dwyer and Boomsma, 2015; Kuruppu and Lodhia, 2019) as it focused on the evolution of an organization run exclusively by volunteers. The analysis shows that whilst a value-based identification is of primary importance in non-profit organizations in general (Chenhall et al., 2017), this is more so when the organization relies on the work of volunteers. The latter do not have an economic relationship with the organization, hence their identification with the mission, values and beliefs of the organization is key for the survival itself of the organization. In such settings, the success of identity management strategies greatly depends on organizational members' leadership ability to transform others into co-authors of the same identity narratives. For this to be possible, the narrative needs to resonate with all members' felt responsibility. The co-construction of organizational identity narrative thus occurs by creating an "alliance around accountability" (Fry, 1995, p. 193) and by engaging in "conversations for accountability" (Fry, 1995, pp. 189-191) wherein organizational members have the opportunity to align organizational identity with their values and beliefs (Agyemang et al, 2017).

The study is subject to two main limitations. Firstly, whilst the study has tried to explain the formation of organizational identity over a period of approximately 5 years $^{2}$, the participatory action research project had a limited duration of 6 months. The organizational members have described those six months as the turning point in the transformation of the organization, thus validating the impact of the 'development phase' on organizational reflexivity. However, inevitably, my analysis has been able to grasp only a very limited 'sample' of the multiple collective identity narratives and hegemonic dynamics that have characterized the transition of WR from an informal grassroots group into a fullyfledged organization during the five years of its existence.

\footnotetext{
${ }^{2}$ From September 2015 when the founders first met, to now.
} 
Second, the present study does not account for the central role that emotions and the affective experience of organizational members play in the construction of organizational identity. The notion itself of felt accountability that I have used to explain the transformational stages requires much more investigation. Feeling responsible involves a complex set of emotions that influence how organizational members identify with the organization, commit to its mission, and interact with colleagues and stakeholders. Building on the findings of this study, future research could thus investigate the role of emotions in shaping not only organizational identity formation but also in creating a shared understanding of accountability.

On a final note, I should add that the nature of the method adopted posed important challenges. During the project, I indeed became one of the many storytellers who inevitably influenced the formation of organizational identity that I was trying to investigate and facilitate. The reports, the business plan, and an initial draft of the paper became some of the narratives around organizational identity and, as such, were not disentangled from hegemonic dynamics taking place within the organization at the time of the research. Enabling the co-construction of a shared narrative around identity and accountability became thus a very difficult objective to achieve given that the research intervention itself resonated with the desires of some organizational members and was ultimately resisted by others. In such research settings, the personal experience of the researcher is loaded with significant ethical challenges and concerns which were not discussed in the context of this paper, but surely deserve further attention and investigation by critical scholars in the future. 


\section{References}

Agyemang, G., O’Dwyer, B. and Unerman, J. (2019), "NGO accountability: retrospective and prospective academic contributions", Accounting, Auditing \& Accountability Journal, Vol. 32 No. 8, pp. 2353-2366.

Agyemang, G., O’Dwyer, B., Unerman, J., \& Awumbila, M. (2017), "Seeking “conversations for accountability" Mediating the impact of non-governmental organization (NGO) upward accountability processes", Accounting, Auditing \& Accountability Journal, Vol. 30 No. 5, pp. $982-$ 1007.

Althusser, L. [1971] (2006), Lenin and philosophy and other essays, Aakar Books, London.

Alvesson, M. (2010), "Self-doubters, strugglers, storytellers, surfers and others: Images of selfidentities in organization studies", Human relations, Vol. 63 No. 5, pp. 193-217.

Baker, C. R. (2014), "Breakdowns of accountability in the face of natural disasters: The case of Hurricane Katrina", Critical Perspectives on Accounting, Vol. 25 No. 7, pp. 620-632.

Brown, A. D. (2006), "A narrative approach to collective identities", Journal of management Studies 43, Vol. 43, No. 4, pp. 731-753.

Butler, J. (2005), Giving an account of oneself, Fordham University Press, New York.

Butler, J. (1990), Gender trouble: Feminism and the subversion of identity, Routledge, New York.

Cameron, J., and Gibson, K. (2005), "Participatory action research in a poststructuralist vein", Geoforum, Vol. 36 No. 3, pp. 315-331.

Carollo, L., and Guerci, M. (2018), “'Activists in a suit': Paradoxes and metaphors in sustainability managers' identity work", Journal of Business Ethics, Vol. 148 No. 2, pp. 249-268.

Chenhall, R. H., M. Hall, and Smith, D. (2017), "The expressive role of performance measurement systems: A field study of a mental health development project", Accounting, Organizations and Society, Vol. 63, pp. 60-75.

Chenhall, R.H., Hall, M. and Smith, D. (2016), "Managing identity conflicts in organizations: a case study of one welfare nonprofit organization", Nonprofit and Voluntary Sector Quarterly, Vol. 45 No. 4, pp. 669-687.

Chenhall, R. H., Hall, M., and Smith, D. (2010), "Social capital and management control systems: A study of a non-government organization", Accounting, organizations and Society, Vol. 35 No. 8, pp. 737-756.

Clegg, S. R., Rhodes, C., and Kornberger, M. (2007), "Desperately seeking legitimacy: Organizational identity and emerging industries", Organization Studies, Vol. 28 No. 4, pp. 495-513.

Cordery, C., Belal, A. R., and Thomson, I. (2019), "NGO accounting and accountability: past, present and future, Accounting Forum, Vol. 43, No. 1, pp. 1-15. 
Corley, K. G., and Gioia, D. A. (2004), "Identity ambiguity and change in the wake of a corporate spinoff", Administrative science quarterly, Vol. 49 No. 2, pp. 173-208.

Costa, E., and Andreaus, M. (2020), "Social impact and performance measurement systems in an Italian social enterprise: a participatory action research project", Journal of Public Budgeting, Accounting \& Financial Management, Vol. ahead-of-print No. ahead-of-print, https://doi.org/10.1108/JPBAFM-02-2020-0012.

Costa, E., Pesci, C., Andreaus, M. and Taufer, E. (2018), "Empathy, closeness, and distance in nonprofit accountability", Accounting, Auditing \& Accountability Journal, Vol. 32 No. 1, pp. 224-254.

Czarniawska, B., and Wolff, R. (1998), "Constructing new identities in established organization fields: Young universities in old Europe”, International Studies of Management \& Organization, Vol. 28 No. 3, pp. 32-56.

Dai, N. T., Free, C., \& Gendron, Y. (2019). Interview-based research in accounting 2000-2014: Informal norms, translation and vibrancy. Management Accounting Research, 42, $26-38$.

Dewi, M. K., Manochin, M., \& Belal, A. R. (2019), "Marching with the volunteers: Their role and impact on beneficiary accountability in an Indonesian NGO", Accounting Auditing and Accountability Journal, Vol. 32 No. 4, pp. 1117-1145.

Dixon R., Ritchie J. and Siwale, J. (2006), "Microfinance: accountability from the grassroots", Accounting, Auditing \& Accountability Journal, Vol. 19 No. 3, pp. 405-427.

Duval, A. M., Gendron, Y., and Roux-Dufort, C. (2015), "Exhibiting nongovernmental organizations: Reifying the performance discourse through framing power”, Critical Perspectives on Accounting, Vol. 29, pp. 31-53.

Ebrahim, A. (2003), "Making sense of accountability: Conceptual perspectives for northern and southern nonprofits." Nonprofit management and leadership, Vol. 14 No. 2, pp. 191-212.

Everett, J., and Friesen, C. (2010), "Humanitarian accountability and performance in the Théâtre de 1'Absurde", Critical Perspectives on Accounting, Vol. 21 No. 6, pp. 468-485.

Elsbach, K. D., (1999), "An expanded model of organizational identification". Research in Organizational Behavior, Vol. 21, pp. 163-200.

Fiol, C. M., and Romanelli, E. (2012), "Before identity: The emergence of new organizational forms", Organization Science, Vol. 23 No. 3, pp. 597-611.

Fry, R. E. (1995), “Accountability in organizational life: Problem or opportunity for nonprofits?”, Nonprofit Management \& Leadership, Vol. 6 No. 2, pp. 181-195.

Giddens A. (1991) Modernity and self-identity, Polity Press, Cambridge.

Gillis, A., and Jackson, W. (2002), Research for nurses: Methods and interpretation, FA Davis Company.

Gioia, D. A., Patvardhan, S. D., Hamilton, A. L., and Corley, K. G. (2013), "Organizational identity formation and change", The academy of management annals, Vol. 7 No. 1, pp. 123-193. 
Gioia, D. A., Price, K. N., Hamilton, A. L., and Thomas, J. B. (2010), "Forging an identity: An insideroutsider study of processes involved in the formation of organizational identity", Administrative science quarterly, Vol. 55 No. 1, pp. 1-46.

Gioia, D. A., Schultz, M., and Corley, K. G. (2000), "Identity dialogues: Where do we go from here", Academy of Management Review, Vol. 25 No.1, pp. 145-147.

Glynn, M.A., and Abzug, R. (2002), "Institutionalizing identity: Symbolic isomorphism and organizational names", Academy of Management Review, Vol. 45 No. 1, pp. 267-280.

Gray, R., Bebbington, J., and Collison, D. (2006), "NGOs, civil society and accountability: making the people accountable to capital", Accounting, Auditing \& Accountability Journal. Vol. 19 No. 3, pp. 319-348.

Kamuf, P. (2007), “Accounterability”, Textual practice, Vol. 21 No. 2, pp. 251-266.

Kelly, P. J. (2005), "Practical suggestions for community interventions using participatory action research", Public Health Nursing, Vol. 22 No. 1, pp. 65-73.

Kroezen, J. J., and Heugens, P. P. M. A. R. (2012), "Organizational identity formation: Processes of identity imprinting and enactment in the Dutch microbrewing landscape", Schultz, M., Maguire, S., Langley, A., and Tsoukas H. (Ed.) Constructing identity in and around organizations, Oxford University Press, Oxford, pp. 89-127.

Kuruppu, S. C., and Lodhia, S. (2019), "Shaping accountability at an NGO: a Bourdieusian perspective”, Accounting, Auditing \& Accountability Journal, Vol. 33 No. 1, pp. 178-203.

Harding, N. (2008), "The "I", the "me" and the "you know": Identifying identities in organisations", Qualitative Research in Organizations and Management, Vol. 3 No.1, pp. 42-58.

Harding, N., Lee, H., and Ford, J. (2014), “Who is 'the middle manager'?”, Human Relations, Vol. 67 No.10, pp. 1213-1237.

Humphreys, M., and A. D. Brown (2002), "Narratives of organizational identity and identification: A case study of hegemony and resistance", Organization studies, Vol. 23 No. 3, pp. 421-447.

Lowe, A., Locke, J., and Lymer, A. (2012), “The SEC's retail investor 2.0: Interactive data and the rise of calculative accountability", Critical Perspectives on Accounting, Vol. 23 No. 3, pp. 183200.

McDonnell, D., and Rutherford, A. C. (2019), "Promoting charity accountability: Understanding disclosure of serious incidents", Accounting Forum, Vol. 43 No. 1, pp. 42-61.

McKernan, J. F. (2012), “Accountability as aporia, testimony, and gift”, Critical Perspectives on Accounting, Vol. 23 No. 3, pp. 258-278.

McPhail, K, Nyamori, R and Taylor, S (2016), "Escaping Accountability: A Case of Australia's Asylum Seeker Policy", Accounting, Auditing \& Accountability Journal Vol. 29 No. 6, pp. $947-$ 984.

Messner, M. (2009), “The limits of accountability”, Accounting, Organizations and Society, Vol. 34 No. 8, pp. 918-938. 
O' Dwyer, B. and Boomsma, R. (2015), "The co-construction of NGO accountability", Accounting, Auditing \& Accountability Journal, Vol. 28 No. 1, pp. 36-68.

O'Dwyer, B., and Unerman, J. (2008), “The paradox of greater NGO accountability: A case study of Amnesty Ireland", Accounting, Organizations and Society, Vol. 33 No. 7-8, pp. 801-824.

O'Leary, S., and Smith, D. (2020), "Moments of resistance: An internally persuasive view of performance and impact reports in non-governmental organizations", Accounting, Organizations and Society, Vol. 85, 101140.

O’Leary, S. (2017), “Grassroots accountability promises in rights-based approaches to development: The role of transformative monitoring and evaluation in NGOs", Accounting, Organizations and Society, Vol. 63, pp.21-41.

Roberts, J. (2009), "No one is perfect: The limits of transparency and an ethic for 'intelligent' accountability", Accounting, Organizations and Society, Vol. 34 No. 8, pp. 957-970.

Roberts, J. (1991), “The possibilities of accountability”, Accounting, organizations and society, Vol. 16 No. 4, pp. 355-368.

Shearer, T. (2002), "Ethics and accountability: from the for-itself to the for-the-other", Accounting, Organizations and Society, Vol. 27 No. 6, pp. 541-573.

Stockenstrand, A. K. (2019), “Accountability dilemmas and identity struggles", Journal of Accounting \& Organizational Change, Vol. 15 No. 1, pp. 2-29.

Sveningsson, S., and Alvesson, M. (2003), "Managing managerial identities: Organizational fragmentation, discourse and identity struggle", Human relations, Vol. 56 No. 10, pp. 1163-1193.

Taylor, D., Tharapos M., and Sidaway S. (2014) "Downward accountability for a natural disaster recovery effort: Evidence and issues from Australia's Black Saturday", Critical Perspectives on Accounting, Vol. 25 No. 7, pp. 633-651.

Uddin, M. M., and Belal, A. R. (2019), “Donors' influence strategies and beneficiary accountability: an NGO case study", Accounting Forum, Vol. 43 No. 1, pp. 113-134.

Unerman, J., and O'Dwyer, B. (2006), “Theorising accountability for NGO advocacy”, Accounting, Auditing \& Accountability Journal, Vol. 19 No. 3, pp. 349-376.

Whetten, D. \& Godfrey, P. (Eds) (1998) Identity in organizations, Sage, London.

Yang, C., and Northcott, D. (2018), "Unveiling the role of identity accountability in shaping charity outcome measurement practices", The British Accounting Review, Vol. 50 No. 2, pp. 214-226.

\section{Other sources}

Kingsley, P. (2015), “10 truths about Europe's migrant crisis”, The Guardian, 10 August.

European Commission (2015), "Communication from the Commission to the European Parliament, the Council, The European Economic and Social Committee and the Committee of the Regions: A European Agenda on Migration". COM (2015) 240 final. 
Table 1. List of interviews and focus group

\begin{tabular}{||llll|}
\hline Interviewree & Day & Duration & \\
Administrative Officer & $26 / 02 / 19$ & $1 \mathrm{~h}$. & Face to face \\
Director (Caseworker A) & $26 / 02 / 19$ & $1 \mathrm{~h}$. & Face to face \\
Director & $27 / 02 / 19$ & $1 \mathrm{~h}$. & Face to face \\
Director & $06 / 03 / 19$ & $1 \mathrm{~h}$. & Face to face \\
Volunteer & $11 / 03 / 19$ & $1 \mathrm{~h}$. & Face to face \\
Chair & $12 / 03 / 19$ & $1 \mathrm{~h}$. & Face to face \\
Director (Caseworker B) & $13 / 03 / 19$ & $1 \mathrm{~h}$. & Face to face \\
Volunteer & $20 / 03 / 19$ & $1 \mathrm{~h}$. & Face to face \\
Volunteer & $28 / 03 / 19$ & $1 \mathrm{~h}$. & Face to face \\
Volunteer & $29 / 03 / 19$ & $1 \mathrm{~h}$. & Face to face \\
Volunteer & $01 / 04 / 19$ & $1 \mathrm{~h}$. & Face to face \\
Volunteer & $26 / 04 / 19$ & $1 \mathrm{~h}$. & Face to face \\
Volunteer & $15 / 07 / 19$ & $1 \mathrm{~h}$. & Face to face \\
10 Beneficiaries & $14 / 04 / 19$ & $1: 30 \mathrm{~h}$. & Focus Group \\
Previous Chair & $06 / 10 / 20$ & $1 \mathrm{~h}$. & Video call \\
Caseworker A & $06 / 10 / 20$ & $1 \mathrm{~h}$. & Video call \\
Current Chair & $14 / 10 / 20$ & $1 \mathrm{~h}$. & Video call \\
Caseworker B & $14 / 10 / 20$ & $1 \mathrm{~h}$ & Video call \\
\hline
\end{tabular}




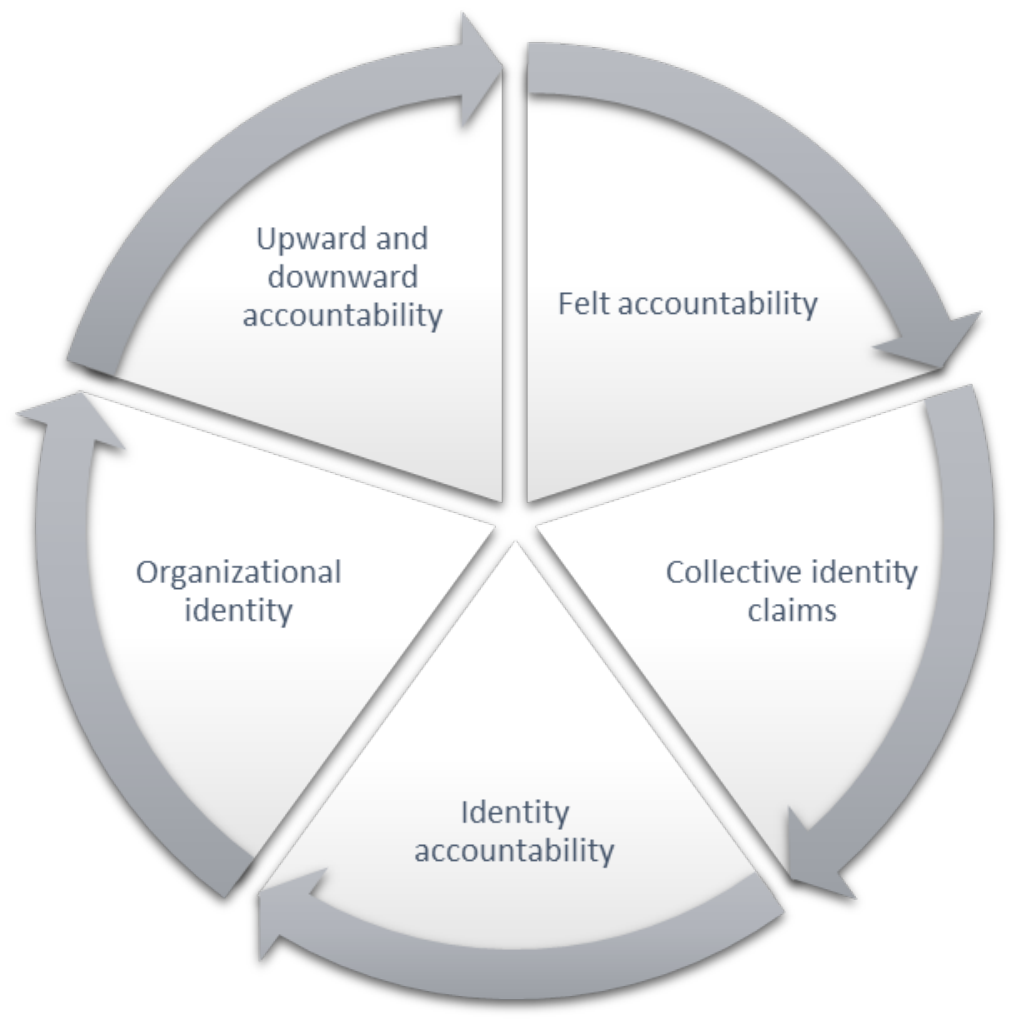

Figure 1 . The identity and accountability cycle 


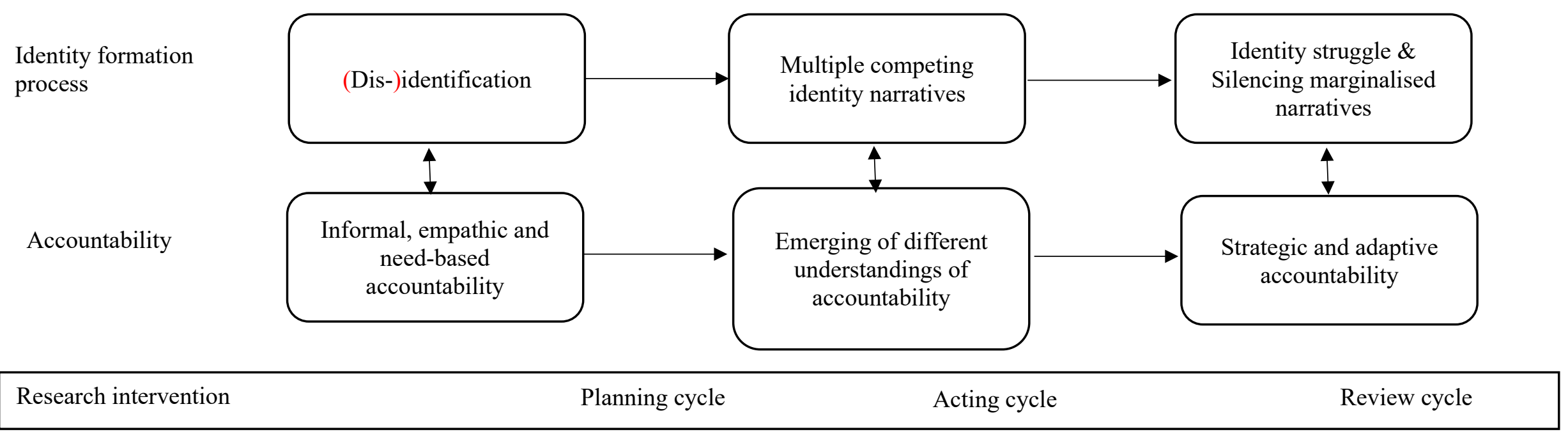

Figure 2. Accountability in identity formation process 